\title{
The Relationship between Human Resource Management (HRM) Practices, Total Quality Management (TQM) Practices and Competitive Advantages
}

\author{
Bader Obeidat $^{1}$, Hadeel Fareed Tawalbeh ${ }^{1} \&$ Ra'ed Masa' deh ${ }^{2}$ \\ ${ }^{1}$ Department of Business Management, School of Business, The University of Jordan, Amman, Jordan \\ ${ }^{2}$ Department of Management Information Systems, School of Business, The University of Jordan, Amman, Jordan \\ Correspondence: Bader Obeidat, Department of Business Management, School of Business, The University of \\ Jordan, Amman, Jordan. E-mail: b.obeidat@ju.edu.jo
}

Received: March19, 2018 Accepted: September 20, 2018 Online Published: October 29, 2018

doi:10.5539/mas.v12n11p17 URL: https://doi.org/10.5539/mas.v12n11p17

\begin{abstract}
This study aimed to investigate the relationship between human resource management (HRM) practices, total quality management (TQM) practices and competitive advantages in Telecommunication organizations in Jordan. A self-administrated questionnaire was designed and distributed over a sample of telecommunication employees of 400 employees. The percentage of filled questionnaires is $80 \%$ (320 questionnaires). The research hypotheses were tested by using multiple regressions. The study concluded that there is a relationship between human resource management practices and total quality management practices. It was also concluded that there is a relationship between total quality management practices and competitive advantage. Finally, there is a relationship between human resource management practices and competitive advantage. A number of recommendations emerged in light of the findings, is that the telecommunication organization are advised to focus more on the human resource management activities and total quality management activities that improve the utilization of competitive advantages.
\end{abstract}

Keywords: human resource management, total quality management, competitive advantages, Jordan

\section{Introduction}

During the last year, organizations have become the most remarkable issue. Having products and services of high quality is crucial for creating a competitive advantage whereby companies can differentiate themselves from competitors and to sustain their businesses. One of the most valued ways to create sustainable competitive advantage is by successfully implementing total quality management (TQM) practices and human resource management (HRM) practices (Usrof \& Elmrsey, 2016). The most important task for many organizations today is to survive the present competitive market through the impact of privatization, liberalization, globalization, competition (Velmurugan \& Akhilesh, 2013). The market environment can become more complex as companies improve competitiveness and the quality of their products and processes. As this takes place, companies can tackle these issues by using HRM and TQM as new approaches to respond effectively to the changes in such an environment (Aragón-Sánchez \& Esteban-Lloret, 2010).

Enhancing the competitiveness of an organization is related to the total quality management, and human resource management practices. Many studies have found TQM to have an impact on competitiveness using quality practices for continually making improvements to meet the need of customer's and to increase a company's competitive advantage. According to Jime'nez-Jime'nez (2009), organizations focus on improving their competitive advantage by using TQM as an approach through which they can enhance the quality of products, human resources, services, processes, and the environment.

According to recent research, HRM practices have the following aims; facilitate employee involvement, provide support for continual company improvement, and systematically eliminate waste while improving both product and service quality by focusing on continual improvement (Alfalla-Luque et al., 2012). Human resource management practices can significantly affect total quality management practices and can also have a huge impact on both employee and customer satisfaction (Ching-Chow, 2006). HRM can be described as a characteristic approach to achieving competitive advantage (Gandhi, 2014). This can be done through an organization's 
capability to convert other resources such as financial capital, machinery, methods and materials into output such as products or services (Pankaj, 2012). It can also be done through the policies and practices for managing people which are integrated with strategic goals and objectives (Tamer \& Darwish, 2009).

Telecommunication companies in Jordan are placed under pressure to control competition, globalization, fluctuation in the marketplace, and growing customer demand. Accordingly this sector must focus on performance competitive advantage and high quality customer service in order to survive in a globally competitive marketplace (Al-dalahmeh et al., 2018; Masa'deh et al., 2018). The demand for telecommunication services has increased rapidly during the last decade due to the changes in lifestyle and the living standards of people. In addition, this demand has been much triggered by the globalization of business operations through all industries along with the labor, capital and resource flexibility that are associated with the industries (Todeva \& John, 2001; Abualoush et al., 2018a, 2018b).

The framework used in this study examines the effect of HRM practices (recruitment and selection, performance appraisals, training and development, compensation and reward) and TQM practices (leadership, continuous improvement, customer satisfaction, employee empowerment, and strategic) on competitive advantage (cost leadership and differentiation) on competitive advantage. Figure 1 depicts the proposed theoretical framework and the three hypotheses with sub-hypotheses are proposed.

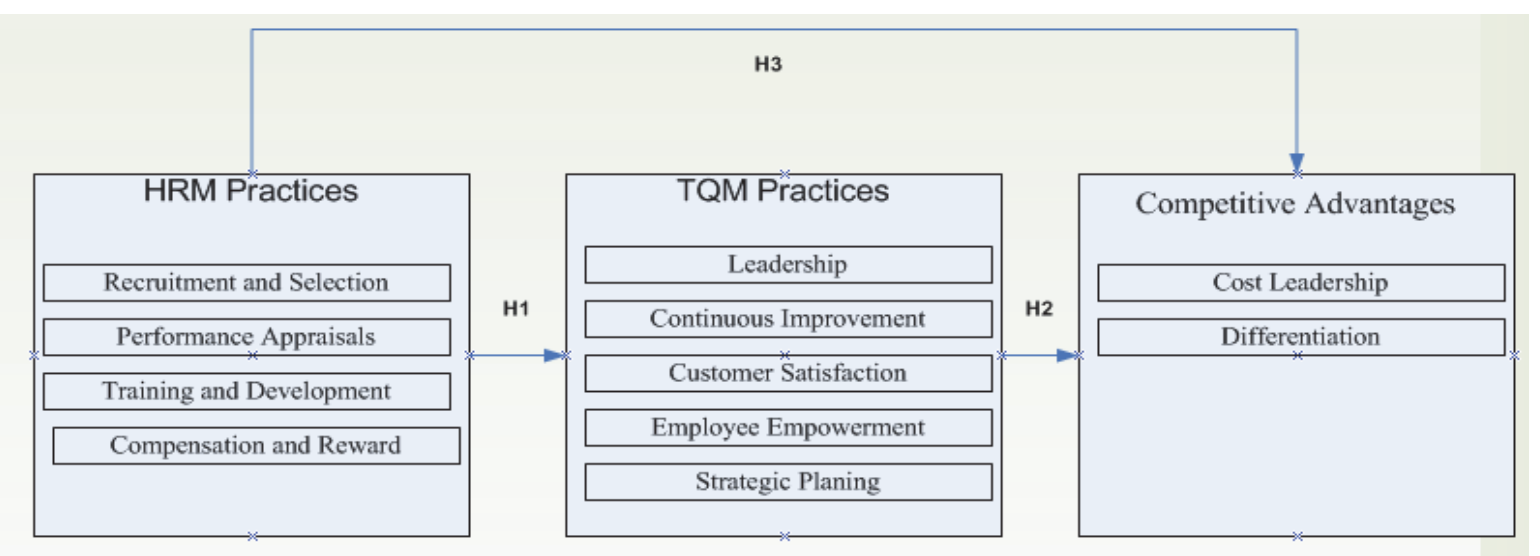

Figure 1. The proposed research framework

H0.1: There is no statistically significant effect at $(\alpha \leq 0.05)$ of human resource management practices on total quality management practices.

Sub-hypotheses:

$\mathrm{H}_{0.1 .1}$ : There is no statistically significant effect at $(\alpha \leq 0.05)$ of recruitment, selection on total quality management practices.

$\mathrm{H}_{0.1 .2}$ : There is no statistically significant effect at $(\alpha \leq 0.05)$ of performance appraisals on total quality management practices.

$\mathrm{H}_{0.1 .3}$ : There is no statistically significant effect at $(\alpha \leq 0.05)$ of training, development on total quality management practices.

$\mathrm{H}_{0.1 .4}$ : There is no statistically significant effect at $(\alpha \leq 0.05)$ of compensation, reward on total quality management practices.

$\mathrm{H}_{0.2}$ : There is no statistically significant effect at $(\alpha \leq 0.05)$ of total quality management practices on competitive advantage.

Sub-hypotheses:

$\mathrm{H}_{0.2 .1}$ : There is no statistically significant effect at $(\alpha \leq 0.05)$ of leadership on competitive advantage.

$\mathrm{H}_{0.2 .2}$ : There is no statistically significant effect at $(\alpha \leq 0.05)$ of continuous improvement on competitive advantage.

$\mathrm{H}_{0.2 .3}$ : There is no statistically significant effect at $(\alpha \leq 0.05)$ of customer satisfaction on competitive advantage. 
$\mathrm{H}_{0.2 .4}$ : There is no statistically significant effect at $(\alpha \leq 0.05)$ of employee empowerment on competitive advantage.

$\mathrm{H}_{0.2 .5}$ : There is no statistically significant effect at $(\alpha \leq 0.05)$ of strategic on competitive advantage.

$\mathrm{H}_{0.3}$ : There is no statistically significant effect at $(\alpha \leq 0.05)$ of human resource management practices on competitive advantage.

Sub-hypotheses:

$\mathrm{H}_{0.3 .1}$ : There is no statistically significant effect at $(\alpha \leq 0.05)$ of recruitment, selection on competitive advantage.

$\mathrm{H}_{0.3 .2}$ : There is no statistically significant effect at $(\alpha \leq 0.05)$ of performance appraisals on competitive advantage.

$\mathrm{H}_{0.3 .3}$ : There is no statistically significant effect at $(\alpha \leq 0.05)$ of training and development on competitive advantage.

$\mathrm{H}_{0.3 .4}$ : There is no statistically significant effect at $(\alpha \leq 0.05)$ of compensation, reward on competitive advantage.

This study focuses on the effect of HRM practices, TQM practices in telecommunication organizations in Jordan. Also, it aims to examine their impact on competitive advantage. This is analyzed using analytical framework through collecting and examining -in depth- information regarding HRM, TQM practices, and competitive advantage. This study shows the importance of having competitive advantage from telecommunication companies through the effect of HRM practices (recruitment and selection, performance appraisals, training and development, compensation and reward), TQM practices (leadership, continuous improvement, customer satisfaction, employee empowerment, and strategic).

Accordingly, this study answers the following questions:

1. To investigate the effect between human resource management practices on competitive advantage.

2. To investigate the effect between total quality management practices on competitive advantage.

3. To investigate the effect between human resource management practices and total quality management practices.

The importance of this study comes firstly from examining the effect of HRM practices (recruitment and selection, performance appraisals, training and development, compensation and reward), TQM practices (leadership, continuous improvement, customer satisfaction, employee empowerment, and strategic) on competitive advantage (cost leadership and differentiation). In addition, this study is crucial for the services and production area, because it is currently a critical point in time to use this area for improving competitive advantage. This led to increase the interest of applying HRM practices and TQM practices (Gelade \& Ivery, 2003). This study tries to increase the awareness of the importance of competitive advantage in telecommunication companies. Also, it highlights the importance of the effect of HRM and TQM practices on improving services and product quality based on competitive advantage.

\section{Research Method}

Although the questionnaire items were adopted from previous items where they proved to be valid and reliable, the questionnaire was pre-tested with 20 respondents and 4 faculty members to ensure its validity before distributing it to the potential respondents. The instrument was modified and redesigned according to the feedback obtained in the pilot study.

The target sample for this survey was Jordanian staff working at different managerial level in the three main telecom operator companies (Zain, Umniah, and Orange). Participation was on a voluntary basis and no financial incentive was offered. This study employed a convenience sampling method as it allows the researchers to select the sample subjects from the targeted population based on who are willing and easily accessible to be recruited in the research. It is also the least expensive, least time-consuming among all other techniques. A total of 400 selfadministered questionnaires were distributed to the employees in these three telecom companies, the number of returned questionnaires were 318 indicating a $80 \%$ response rate. Of the 318 participants, the gender split was 194 $(60.8 \%)$ male and 125 (39.2\%) female. Their age range varied from 20 to 39 years old, with $57.1 \%$ below 23 years old. In terms of their academic qualifications, the majority of the participants (233 participants) hold a bachelor degree and $13 \%$ (42 participants) hold a master degree.

The questionnaire consists of 71 questions adopted from established items previously used for measuring each 
HRM practices, TQM practices and competitive advantage. More specifically, the items measures the TQM practices were adopted from Anil \& Satish (2016), Sweis et al. (2015), Wiengartena et al. (2013) and Kaur \& Sharma (2014) using leadership, continuous improvement, customer satisfaction, employee empowerment, and strategic planning. While HRM practices were adopted from Obeidat et al. (2014) and Dedy et al., (2016) using recruitment and selection, performance appraisals, training and development, compensation and reward. These items were measured using 5-point Likert scale ranging from 1- strongly disagrees to 5-strongly agree.

\section{Results}

Table (1) presents a complete list of respondents' demographic characteristics in terms of age, gender, qualification, and years of experience. Based on this table the following can be observed:

Table 1. Demographic characteristics of respondents

\begin{tabular}{llll}
\hline Variable & Category & Frequency & Percent \\
\hline \multirow{4}{*}{ Age } & 20 less than 30 & 182 & $57.1 \%$ \\
& 31 less than 40 & 108 & $33.9 \%$ \\
Gender & 41 less than 50 & 29 & $9.0 \%$ \\
& Male & 194 & $60.8 \%$ \\
\multirow{5}{*}{ Qualification } & Female & 125 & $39.2 \%$ \\
& Tawjehi & 17 & $5.3 \%$ \\
& Diploma & 28 & $8.8 \%$ \\
& B.Sc. & 233 & $73.0 \%$ \\
Years of Experience & MA & 37 & $11.6 \%$ \\
& PhD & 4 & $1.3 \%$ \\
& 0 less than 5 & 154 & $48.3 \%$ \\
& 6 less than 10 & 112 & $35.1 \%$ \\
& More than 10 & 53 & $16.6 \%$ \\
\hline
\end{tabular}

In regard to the gender, the majority of the samples were males $(60.8 \%)$ and female represent $(39.2 \%)$ of the sample. Most age of employee whose worked in telecommunication organization between 20 less than 30 and represent (57.1\%), then 31 less than 40 represent (33.9\%), with a few percentage for employee age between 41 and less than 50 represent $(9.0 \%)$.For the qualification the majority of employee has a bachelor degree response (73.0\%), with small percentage for Ph.D. level represent (1.3\%) and master degree represent (11.6\%) for diploma degree represent $(8.8 \%)$, finally Tawjehi degree represent (5.3\%). The experience of employee as shown in Table (4) $(48.3 \%)$ have an experience the less than five years while (35.1\%) have six years and less than ten years, and finally $(16.6 \%)$ have above ten years.

The result shows that the age between 20-30 years represents about half of the respondents and majority of them hold a bachelor degree. This may suggest that these groups highly known importance of HRM practices and TQM practices in improving work purpose. From the result, it can also be seen that number of male are more than female which may imply that men have more time to apply HRM practices and TQM practices. Finally, according to the findings people with less than 5 years of experience gives effective competitive advantage to organization other than seiner employees.

The mean, standard deviation (SD) and the level of this item based on its mean the level of each item determined by (highest point in likert scale - lowest point in likert scale) / number of the levels used = the interval between each level and the another $=1.33$ where 1-2.33 reflected by "Low", 2.34-3.67 reflected by "Moderate" and 3.685 reflected by "High". The study is presented as follows:

\subsection{HRM Practices}

\subsubsection{Recruitment \& Selection}

The mean and standard deviation measurements were used to describe and analyze the level of HRM Practices/ Recruitment \& Selection, as shown in table (2). 
Table 2. Mean, SD, and importance level of recruitment \& selection

\begin{tabular}{|c|c|c|c|c|c|}
\hline Rank & No. & Item & Mean & SD & Mean Level \\
\hline 1 & 1 & $\begin{array}{l}\text { The Company follows administrative policies in the } \\
\text { selection and recruitment process. }\end{array}$ & 3.65 & 1.02 & Moderate \\
\hline 2 & 6 & $\begin{array}{l}\text { The company is interested in the selection and } \\
\text { appointment applicant's ability to work within team } \\
\text { operations. }\end{array}$ & 3.65 & 1.049 & Moderate \\
\hline 3 & 5 & $\begin{array}{l}\text { Stimulate the selection and recruitment policies working } \\
\text { to develop their administrative skills. }\end{array}$ & 3.59 & 1.033 & Moderate \\
\hline 4 & 3 & $\begin{array}{l}\text { The company is interested to gather information about } \\
\text { applicants to fill vacancies for the purpose of use in the } \\
\text { differentiation and appointment. }\end{array}$ & 3.57 & 1.034 & Moderate \\
\hline 5 & 2 & $\begin{array}{l}\text { The company appoints the personnel that possess the } \\
\text { skills and experience sufficient to fill management } \\
\text { positions. }\end{array}$ & 3.53 & 1.06 & Moderate \\
\hline 6 & 4 & $\begin{array}{l}\text { Strengthen the selection processes and recruitment of } \\
\text { free and fair competition among candidates. }\end{array}$ & 3.29 & 1.084 & Moderate \\
\hline \multicolumn{3}{|c|}{ Recruitment \& Selection } & 3.55 & 0.869 & Moderate \\
\hline
\end{tabular}

Table (2) shows the mean, standard deviation and importance level of Recruitment \& Selection. The mean of recruitment \& selection items ranged between (3.29-3.65), compared to the general mean value of (3.55). It is observed that the highest mean was for the statement "The Company follows administrative policies in the selection and Recruitment process" with a mean of (3.65), and a standard deviation of (1.02). The lowest mean was for the statement "Strengthen the selection processes and recruitment of free and fair competition among candidates" with a value of (3.29) and a standard deviation of (1.084). In general, it appears that the Importance level of recruitment \& selection was moderate. This means that recruitment and selection practice in telecommunication organization in Jordan is based on some criteria and standards, and it is very sensitive to new employee, which indicates that the company is moderately applying the recruitment $\&$ selection practice.

\subsubsection{Performance Appraisal}

The mean and standard deviation measurements were used to describe and analyze the level of HRM Practices/ Performance Appraisal, as shown in table (3).

Table 3. Mean, SD, and importance level of performance appraisal

\begin{tabular}{|c|c|c|c|c|c|}
\hline Rank & No. & Item & Mean & SD & Mean Level \\
\hline 1 & 1 & $\begin{array}{l}\text { The company has available system for evaluating the } \\
\text { performance of staff. }\end{array}$ & 3.99 & 1.023 & High \\
\hline 2 & 2 & $\begin{array}{l}\text { The company attaches importance to the application } \\
\text { of performance evaluation and follow-up system }\end{array}$ & 3.87 & 0.976 & High \\
\hline 3 & 3 & $\begin{array}{l}\text { The employee receives feedback from the direct } \\
\text { manager about his performance. }\end{array}$ & 3.67 & 1.001 & Moderate \\
\hline 4 & 6 & $\begin{array}{l}\text { Performance evaluation helps to clarify the strengths } \\
\text { and weaknesses of the employee's performance. }\end{array}$ & 3.62 & 1.072 & Moderate \\
\hline 5 & 4 & $\begin{array}{l}\text { The company revision the criteria for performance } \\
\text { evaluation system periodically. }\end{array}$ & 3.49 & 1.098 & Moderate \\
\hline 6 & 7 & $\begin{array}{l}\text { The company provides effective training programs } \\
\text { to enhance the skills of the staff based on the results } \\
\text { of performance evaluation. }\end{array}$ & 3.48 & 1.072 & Moderate \\
\hline 7 & 5 & $\begin{array}{l}\text { Evaluation system applied in the company provides } \\
\text { an opportunity for communication between the } \\
\text { employee and the manager. }\end{array}$ & 3.43 & 1.136 & Moderate \\
\hline \multicolumn{3}{|c|}{ Performance Appraisal } & 3.65 & 0.836 & Moderate \\
\hline
\end{tabular}

Table (3) shows the mean, standard deviation and importance level of performance appraisal. The mean of 
performance appraisal items ranged between (3.43-3.99), compared to the general mean value of (3.65). It is observed that the highest mean was for the statement " The company has available system for evaluating the performance of staff" with a mean of (3.99), and a standard deviation of (1.023). The lowest mean was for the statement Evaluation system applied in the company provides an opportunity for communication between the employee and the manager" with a value of (3.43) and a standard deviation of (1.136). In general, it appears that the Importance level of performance appraisal was moderate. The result indicates the performance appraisal practice in telecommunication organization in Jordan is implemented due to its importance either for employee or for company.

\subsubsection{Training and Development}

The mean and standard deviation measurements were used to describe and analyze the level of HRM Practices/ training and development, as shown in table (4).

Table 4. Mean, SD, and importance level of training and development

\begin{tabular}{llllll}
\hline Rank & No. & Item & Mean & SD & $\begin{array}{l}\text { Mean } \\
\text { Level }\end{array}$ \\
\hline 1 & 5 & $\begin{array}{l}\text { The company provision of appropriate training for staff as required } \\
\text { by the nature of the work of all of them. } \\
\text { the company through regular plan and a variety of tools identify of } \\
\text { training needs }\end{array}$ & 3.73 & 0.99 & High \\
2 & 3 & $\begin{array}{l}\text { Characterized by the training programs offered to employees in the } \\
\text { company's realistic and relevant document needs }\end{array}$ & 3.71 & 1.011 & High \\
4 & 1 & $\begin{array}{l}\text { The company relies regular training programs for the development } \\
\text { of the performance of the new workers in the skills necessary for } \\
\text { them. }\end{array}$ & 3.64 & 1.011 & Moderate \\
5 & 2 & $\begin{array}{l}\text { In your Organization, learning is planned and purposeful rather } \\
\text { than accidental }\end{array}$ & 3.51 & 1.046 & Moderate \\
6 & 6 & $\begin{array}{l}\text { Training programs provide the opportunity to exchange } \\
\text { information, knowledge and experiences among participants. }\end{array}$ & 3.26 & 1.184 & Moderate \\
Training and Development & 3.61 & 0.847 & Moderate \\
\hline
\end{tabular}

Table (4) shows the mean, standard deviation and importance level of training and development. The mean of training and development items ranged between (3.26-3.82), compared to the general mean value of (3.61). It is observed that the highest mean was for the statement "The company provision of appropriate training for staff as required by the nature of the work of all of them" with a mean of (3.82), and a standard deviation of (0.99). The lowest mean was for the statement "Training programs provide the opportunity to exchange information, knowledge and experiences among participants" with a value of (3.26) and a standard deviation of (1.184). In general, it appears that the Importance level of training and development was moderate. The result indicates the training and development practice in telecommunication organization in Jordan is one of the main activates, and each employee need to be trained and skill development.

\subsubsection{Compensation and Reward}

The mean and standard deviation measurements were used to describe and analyze the level of HRM Practices/ compensation and reward, as shown in table (5).

Table 5. Mean, SD, and importance level of compensation and reward

\begin{tabular}{llllll}
\hline Rank & No. & Item & Mean & SD & Mean Level \\
\hline 1 & 5 & $\begin{array}{l}\text { The company revision of the compensation and } \\
\text { reward system based on the company's competitive } \\
\text { environment. }\end{array}$ & 0.977 & High \\
2 & $1 \quad \begin{array}{l}\text { Senior management of the company stimulate the } \\
\text { staff through the application of compensation and } \\
\text { reward system } \\
\text { compensation and reward processes for employees } \\
\text { based on the principles and criteria evaluation }\end{array}$ & 1.1 & 1.13 & Moderate
\end{tabular}




\begin{tabular}{llllll}
4 & 3 & $\begin{array}{l}\text { Appropriate compensation and reward offered by the } \\
\text { company with the staff's expectations. }\end{array}$ & 1.213 & Moderate \\
5 & $2 \quad \begin{array}{l}\text { compensation and reward system contributes to the } \\
\text { company encouraged employees to achieve the } \\
\text { company's goals }\end{array}$ & 1.318 & Moderate \\
Compensation and Reward & 3.18 & 0.936 & Moderate \\
\hline
\end{tabular}

Table (5) shows the mean, standard deviation and importance level of compensation and reward. The mean of compensation and reward items ranged between (2.84-3.70), compared to the general mean value of (3.18). It is observed that the highest mean was for the statement "The company revision of the compensation and reward system based on the company's competitive environment" with a mean of (3.70), and a standard deviation of (0.977). The lowest mean was for the statement "compensation and reward system contributes to the company encouraged employees to achieve the company's goals" with a value of (2.84) and a standard deviation of (1.318). In general, it appears that the Importance level of compensation and reward was moderate. This result in general indicates that telecommunication organization in Jordan is interested to provide employee with benefit that can improve their competitive advantage.

\subsection{TQM Practices}

\subsubsection{Leadership}

The mean and standard deviation measurements were used to describe and analyze the level of TQM Practices/ leadership, as shown in table (6).

Table 6. Mean, SD, and importance level of leadership

\begin{tabular}{|c|c|c|c|c|c|}
\hline Rank & No. & Item & Mean & SD & Mean Level \\
\hline 1 & 4 & $\begin{array}{l}\text { Management believes that quality is the way and } \\
\text { philosophy in the conduct of its business. }\end{array}$ & 4.07 & 0.993 & High \\
\hline 2 & 2 & $\begin{array}{l}\text { Leadership is working to spread the culture of quality } \\
\text { in all departments and administrative levels. }\end{array}$ & 3.98 & 0.994 & High \\
\hline 3 & 3 & $\begin{array}{l}\text { The company is working hard to be the company's } \\
\text { outstanding services. }\end{array}$ & 3.91 & 0.999 & High \\
\hline 4 & 1 & $\begin{array}{l}\text { The company has clear plan about the quality of certain } \\
\text { specific goals and committed management application. }\end{array}$ & 3.8 & 0.987 & High \\
\hline 5 & 5 & $\begin{array}{l}\text { Leaders seek to build a reputation among customers, } \\
\text { based on the quality and workmanship }\end{array}$ & 3.74 & 1.06 & High \\
\hline 6 & 6 & $\begin{array}{l}\text { Adopts senior management standards of quality in the } \\
\text { work encourages outstanding performance among } \\
\text { employees Environment }\end{array}$ & 3.73 & 0.932 & High \\
\hline \multicolumn{2}{|c|}{ Leadership } & & 3.87 & 0.813 & High \\
\hline
\end{tabular}

Table (6) shows the mean, standard deviation and importance level of leadership. The mean of leadership items ranged between (3.73-4.07), compared to the general mean value of (3.87). It is observed that the highest mean was for the statement "Management believes that quality is the way and philosophy in the conduct of its business" with a mean of (4.07), and a standard deviation of (0.993). The lowest mean was for the statement "Adopts senior management standards of quality in the work encourage outstanding performance among employees Environment" with a value of (3.73) and a standard deviation of (0.932). In general, it appears that the Importance level of leadership was high. The above table shows that almost all items of leadership have a high level of importance, which helps to maximize efficiency and to achieve organizational goals.

\subsubsection{Continuous Improvement}

The mean and standard deviation measurements were used to describe and analyze the level of TQM Practices/ continuous improvement, as shown in table (10). 
Table 7. Mean, SD, and importance level of continuous improvement

\begin{tabular}{|c|c|c|c|c|c|}
\hline Rank & No. & Item & Mean & SD & Mean Level \\
\hline 1 & 7 & $\begin{array}{l}\text { The company is constantly working to get rid of } \\
\text { activities that do not add value to the service }\end{array}$ & 3.98 & 0.902 & High \\
\hline 2 & 3 & $\begin{array}{l}\text { Management relies on advanced technological } \\
\text { programs }\end{array}$ & 3.93 & 0.937 & High \\
\hline 3 & 4 & $\begin{array}{l}\text { The company is based on the results of its } \\
\text { performance compared to competitors in the } \\
\text { development of plans to improve performance }\end{array}$ & 3.89 & 0.971 & High \\
\hline 4 & 2 & $\begin{array}{l}\text { the company engage employee in the development } \\
\text { plans to achieve quality }\end{array}$ & 3.83 & 1.015 & High \\
\hline 5 & 5 & $\begin{array}{l}\text { the company monitor the extent of improvement in } \\
\text { the quality of services provided by the company and } \\
\text { compare it to previous years }\end{array}$ & 3.68 & 1.058 & High \\
\hline 6 & 6 & $\begin{array}{l}\text { There is a continuous improvement in working } \\
\text { conditions and conditions }\end{array}$ & 3.58 & 1.078 & Moderate \\
\hline 7 & 1 & $\begin{array}{l}\text { There is a clear and specific strategy that includes } \\
\text { improving the quality of work plans }\end{array}$ & 3.43 & 1.093 & Moderate \\
\hline \multicolumn{3}{|c|}{ Continuous Improvement } & 3.76 & 0.773 & High \\
\hline
\end{tabular}

Table (7) shows the mean, standard deviation and importance level of continuous improvement. The mean of continuous improvement items ranged between (3.43-3.98), compared to the general mean value of (3.76). It is observed that the highest mean was for the statement " The company is constantly working to get rid of activities that do not add value to the service" with a mean of (3.98), and a standard deviation of (0.902). The lowest mean was for the statement "There is a clear and specific strategy that includes improving the quality of work plans" with a value of (3.43) and a standard deviation of (1.093). In general, it appears that the Importance level of continuous improvement was high. The above table shows that almost all items of leadership have a high level of importance, which it important to improve services, products and even processes.

\subsubsection{Customer Satisfaction}

The mean and standard deviation measurements were used to describe and analyze the level of TQM Practices/ customer satisfaction, as shown in table (8).

Table 8. Mean, SD, and importance level of customer satisfaction

\begin{tabular}{llllll}
\hline Rank & No. & Item & Mean & SD & Mean Level \\
\hline 1 & 3 & $\begin{array}{l}\text { The company focuses on achieving customer } \\
\text { satisfaction through the study of their } \\
\text { requirements. }\end{array}$ & 0.957 & High \\
2 & 2 & $\begin{array}{l}\text { The company responds quickly to meet the wishes } \\
\text { of customers. } \\
\text { The company's management realizes study the }\end{array}$ & 0.931 & High \\
market to know the needs and desires of \\
consumers.
\end{tabular}

Table (8) shows the mean, standard deviation and importance level of customer satisfaction. The mean of customer satisfaction items ranged between (3.39-4.00), compared to the general mean value of (3.82). It is observed that 
the highest mean was for the statement "The company focuses on achieving customer satisfaction through the study of their requirements" with a mean of (4.00), and a standard deviation of (0.957). The lowest mean was for the statement "The company is fully covered for the various needs of the market" with a value of (3.39) and a standard deviation of (1.082). In general, it appears that the Importance level of customer satisfaction was high. Almost all customer satisfaction items have a high level of important which mean that the telecommunication organizations in Jordan are highly focuses in customer need and satisfaction, which it help predict future revenue and help to outpace your competition.

\subsubsection{Employee Empowerment}

The mean and standard deviation measurements were used to describe and analyze the level of TQM Practices/ employee empowerment, as shown in table (9).

Table 9. Mean, SD, and importance level of employee empowerment

\begin{tabular}{llllll}
\hline Rank & No. & Item & Mean & SD & Mean Level \\
\hline 1 & 5 & $\begin{array}{l}\text { The company management give material or moral } \\
\text { rewards to employees for their participation in } \\
\text { achieving outstanding performance. } \\
2\end{array}$ & $\begin{array}{l}\text { The company management authorizes for workers } \\
\text { the powers to act in emergency situations. }\end{array}$ & 0.95 & High \\
3 & 3 & $\begin{array}{l}\text { The company management provides freedom for } \\
\text { workers to make decisions independently }\end{array}$ & 1.17 & Moderate \\
4 & 1 & $\begin{array}{l}\text { The company is interested in the participation of all } \\
\text { workers to improve quality and performance. }\end{array}$ & 3.14 & 1.151 & Moderate \\
5 & 2 & $\begin{array}{l}\text { Employees are involved in the preparation of plans } \\
\text { to improve quality. }\end{array}$ & 2.99 & 1.183 & Moderate \\
Employee Empowerment & 3.23 & 0.949 & Moderate \\
\hline
\end{tabular}

Table (9) shows the mean, standard deviation and importance level of employee empowerment. The mean of employee empowerment items ranged between (2.99-3.68), compared to the general mean value of (3.23). It is observed that the highest mean was for the statement "The company management gives material or moral rewards to employees for their participation in achieving outstanding performance" with a mean of (3.68), and a standard deviation of (0.95). The lowest mean was for the statement "Employees are involved in the preparation of plans to improve quality" with a value of (2.99) and a standard deviation of (1.183). In general, it appears that the Importance level of employee empowerment was medium. When employees are confident within their work and with their employer, they are more willing to identify problems and suggest ways to improve quantity and quality of output.

\subsubsection{Strategic}

The mean and standard deviation measurements were used to describe and analyze the level of TQM Practices/ strategic, as shown in table (10).

Table 10. Mean, SD, and importance level of strategic

\begin{tabular}{llllll}
\hline Rank & No. & Item & Mean & SD & Mean Level \\
\hline 1 & 4 & $\begin{array}{l}\text { The company management uses scientific methods and } \\
\text { advanced technological tools for the purpose of } \\
\text { achieving its strategic plan. }\end{array}$ & 0.971 & High \\
2 & $3 \quad \begin{array}{l}\text { The company is seeking to modify its strategic } \\
\text { objectives according to the changing needs in a } \\
\text { competitive market }\end{array}$ & $\begin{array}{l}\text { The strategic goals of the company are related to its } 3.86 \\
\text { mission and vision of the future }\end{array}$ & 0.918 & High \\
3 & 5 & 1 & $\begin{array}{l}\text { The company management aware the concept of } 3.82 \\
\text { strategic planning and the fields. }\end{array}$ & High \\
5 & 6 & $\begin{array}{l}\text { The company set a timetable appropriate to achieve } 3.76 \\
4\end{array}$ & High \\
\hline
\end{tabular}




$\begin{array}{llllll}6 & 2 \quad \begin{array}{l}\text { each strategic goal } \\ \text { The company choose appropriate strategies to achieve } \\ \text { the most appropriate to fit internal and external } \\ \text { conditions by the present and future }\end{array} & 0.925 & \text { High } \\ \text { Strategic } & \text { 3. } & & 0.787 & \text { High }\end{array}$

Table (10) shows the mean, standard deviation and importance level of strategic. The mean of strategic items ranged between (3.74-3.90), compared to the general mean value of (3.83). It is observed that the highest mean was for the statement "The company management uses scientific methods and advanced technological tools for the purpose of achieving its strategic plan" with a mean of (3.90), and a standard deviation of (0.941). The lowest mean was for the statement "The company choose appropriate strategies to achieve the most appropriate to fit internal and external conditions by the present and future" with a value of (3.74) and a standard deviation of (0.925). In general, it appears that the Importance level of strategic was high. The above table shows that almost all items of leadership have a high level of importance. It is fundamental to the success and sustainability of any organization.

\subsection{Competitive Advantage}

\subsubsection{Cost Leadership}

The mean and standard deviation measurements were used to describe and analyze the level of competitive advantage/ cost leadership, as shown in table (11).

Table 11. Mean, SD, and importance level of cost leadership

\begin{tabular}{|c|c|c|c|c|c|}
\hline Rank & No. & Item & Mean & SD & Mean Level \\
\hline 1 & 6 & $\begin{array}{l}\text { The company works to achieve a distinctive brand of } \\
\text { their services compared to competitors }\end{array}$ & 4.03 & 0.883 & High \\
\hline 2 & 5 & $\begin{array}{l}\text { The company is working to develop a rapid and } \\
\text { effective distribution channels for the delivery of its } \\
\text { services to customers better than competitors }\end{array}$ & 4.01 & 0.911 & High \\
\hline 3 & 3 & $\begin{array}{l}\text { The company is seeking to gain access to new } \\
\text { markets are difficult to access by competitors. }\end{array}$ & 3.99 & 0.887 & High \\
\hline 4 & 4 & $\begin{array}{l}\text { The company is working to provide new services and } \\
\text { benefits from competitors }\end{array}$ & 3.95 & 0.901 & High \\
\hline 5 & 1 & $\begin{array}{l}\text { The company employs advanced technologies in the } \\
\text { provision of services }\end{array}$ & 3.88 & 0.909 & High \\
\hline 6 & 2 & $\begin{array}{l}\text { The company offers its services in a manner to } \\
\text { ensure excellence and uniqueness of all competitors }\end{array}$ & 3.88 & 0.838 & High \\
\hline \multicolumn{2}{|c|}{ Cost Leadership } & & 3.96 & 0.728 & High \\
\hline
\end{tabular}

Table (11) shows the mean, standard deviation and importance level of cost leadership. The mean of cost leadership items ranged between (3.88-4.03), compared to the general mean value of (3.96). It is observed that the highest mean was for the statement "The company works to achieve a distinctive brand of their services compared to competitors" with a mean of (4.03), and a standard deviation of (0.883). The lowest mean was for the statement "The company offers its services in a manner to ensure excellence and uniqueness of all competitors" with a value of (3.88) and a standard deviation of (0.838). In general, it appears that the importance level of cost leadership was high. The above table shows that almost all items of leadership have a high level of importance.

\subsubsection{Differentiation Advantage}

The mean and standard deviation measurements were used to describe and analyze the level of competitive advantage/ differentiation advantage, as shown in table (12). 
Table 12. Mean, SD, and importance level of differentiation advantage

\begin{tabular}{|c|c|c|c|c|c|}
\hline Rank & No. & Item & Mean & SD & Mean Level \\
\hline 1 & 5 & $\begin{array}{l}\text { The company is seeking to get the price advantages } \\
\text { of suppliers to reduce costs }\end{array}$ & 4.08 & 0.905 & High \\
\hline 2 & 4 & $\begin{array}{l}\text { The company is working to control administrative } \\
\text { cost }\end{array}$ & 4.06 & 1.023 & High \\
\hline 3 & 3 & $\begin{array}{l}\text { The company is working to reduce distribution costs } \\
\text { and promote as much as possible }\end{array}$ & 3.87 & 1.024 & High \\
\hline 4 & 2 & $\begin{array}{l}\text { The company employs its potential to meet the needs } \\
\text { and specific requirements in the local market the } \\
\text { lowest possible cost }\end{array}$ & 3.84 & 0.894 & High \\
\hline 5 & 1 & $\begin{array}{l}\text { The company is working on the optimal utilization } \\
\text { of available resources in order to achieve } \\
\text { competitiveness at all levels }\end{array}$ & 3.79 & 0.864 & High \\
\hline 6 & 6 & $\begin{array}{l}\text { The company is seeking to enhance the productivity } \\
\text { of individuals within the physical capabilities }\end{array}$ & 3.78 & 1.013 & High \\
\hline \multicolumn{3}{|c|}{ Differentiation Advantage } & 3.90 & 0.743 & High \\
\hline
\end{tabular}

Table (12) shows the mean, standard deviation and importance level of differentiation advantage. The mean of differentiation advantage items ranged between (3.78-4.08), compared to the general mean value of (3.92). It is observed that the highest mean was for the statement "The company is seeking to get the price advantages of suppliers to reduce costs" with a mean of (4.08), and a standard deviation of (0.905). The lowest mean was for the statement "The company is seeking to enhance the productivity of individuals within the physical capabilities" with a value of (3.78) and a standard deviation of (1.013). In general, it appears that the Importance level of differentiation advantage was high. The above table shows that almost all items of leadership have a high level of importance.

\subsection{Descriptive Statistics of the Constructs}

The descriptive statistics showed that the majority of participants indicate positive responses to the constructs that are measured in this study (see Table 13). All means were greater than the mid-point 2.5 and also the standard deviation ranged between 0.73 to 0.93 which indicated a narrow spread around the mean. The reliability of the data was measured using Cronbach's Alpha. According to Sekaran and Bougie (2010), if Cronbach's Alpha is closer to 1 , the reliability of the measures is higher. A Cronbach's Alpha of 0.6 is considered poor, while 0.7 is acceptable and 0.8 is categorized as good. As can be shown in Table 13, the results show that the constructs has adequate reliability.

Table 13. Reliability analysis using the approach of cronbach's alpha

\begin{tabular}{lllll}
\hline Number & Item & Cronbach's Alpha & Mean & SD \\
\hline 1 & Recruitment and Selection & 0.94 & 3.55 & 0.869 \\
2 & Performance Appraisals & 0.91 & 3.65 & 0.836 \\
3 & Training and Development & 0.90 & 3.61 & 0.847 \\
4 & Compensation and Reward & 0.94 & 3.18 & 0.936 \\
\hline Human Resource Management Practices & 0.95 & 3.50 & 0.872 \\
\hline 1 & Leadership & 0.95 & 3.87 & 0.813 \\
2 & Continuous Improvement & 0.93 & 3.76 & 0.773 \\
3 & Customer Satisfaction & 0.93 & 3.82 & 0.817 \\
4 & Employee Empowerment & 0.90 & 3.23 & 0.949 \\
5 & Strategic & 0.95 & 3.83 & 0.787 \\
\hline Total Quality Management Practices & 0.96 & 3.66 & 0.813 \\
\hline 1 & Differentiation & 0.89 & 3.90 & 0.743 \\
2 & Cost Leadership & 0.88 & 3.96 & 0.728 \\
\hline Competitive Advantage & 0.91 & 3.93 & 0.733 \\
\hline \multicolumn{4}{l}{}
\end{tabular}




\subsection{Hypotheses Testing}

A correlation analysis was performed to determine the effect of the four HRM practices, the five TQM practices on the two competitive advantages. Second, inferential statistics using multiples regression were used to test the hypotheses of the research.

H0.1: There is no statistically significant effect at $(\alpha \leq 0.05)$ of human resource management practices on total quality management practices.

Multiple regressions were used to test the effect of human resource management practices on total quality management practices, at a confidence level of (95\%), and table (14) shows that:

Table 14. Multiple regression analysis of the effect of human resource management practices on total quality management practices

\begin{tabular}{|c|c|c|c|c|c|c|c|c|}
\hline Variables & $\mathrm{R}$ & $\mathrm{R}^{2}$ & $\begin{array}{l}\text { Adjusted } \\
\mathrm{R}^{2}\end{array}$ & F-value & Sig*. & $\begin{array}{l}\text { Standardized } \\
\text { Beta }\end{array}$ & $\begin{array}{l}\mathrm{t}- \\
\text { value }\end{array}$ & Sig*. \\
\hline & 0.875 & 0.766 & 0.763 & 257.055 & $0.00 *$ & & & \\
\hline $\begin{array}{l}\text { Recruitment } \\
\text { Selection }\end{array}$ & & & & & & 0.239 & 5.782 & $0.00^{*}$ \\
\hline Performance Appraisal & & & & & & 0.215 & 4.829 & $0.00^{*}$ \\
\hline $\begin{array}{ll}\text { Training } & \text { and } \\
\text { Development } & \end{array}$ & & & & & & 0.465 & 0.956 & $0.00^{*}$ \\
\hline $\begin{array}{l}\text { Compensation and } \\
\text { Reward }\end{array}$ & & & & & & 0.078 & 2.162 & $0.031 *$ \\
\hline
\end{tabular}

The correlation coefficient $\mathrm{R}=0.875$ indicates that there is a positive correlation between human resource management practices and total quality management practices. The $\mathrm{R}^{2}$ value is 0.766 ; therefore, the model is regarded as being fit to be used for multiple regressions with the data. The results of the multiple regression analysis that regress the four sub variables human resource management practices are shown on table (14). It shows that the four sub-variables together explained $76.6 \%$ of the variance, where $\left(\mathrm{R}^{2}=0.766, \mathrm{~F}=257.055\right.$, Sig. $\left.=0.00\right)$. Therefore, the null hypothesis is rejected and the alternative hypothesis is accepted, which states that there is effect of human resource management practices (Recruitment \& Selection, Performance Appraisal, Training and Development, Compensation and Reward) on total quality management practices, at level $(\alpha \leq 0.05)$.

In addition to table (14) shows that the training and development sub-variable has the most contribution on total quality management practices, where (Beta $=0.465$, sig. $=0.00$ ). Thus, it indicates that the training and development sub-variable is the most significant, and it positively and directly regresses to total quality management practices. Followed by recruitment $\&$ selection sub-variable, where $($ Beta $=0.239$, sig. $=0.00)$, then performance appraisal sub variable, where $(B e t a=0.215$, sig. $=0.00)$. Finally, compensation and reward sub-variable where $(B e t a=0.078$, sig. $=0.031$ ).

The analysis indicates that there is statistically significance effect of human resources management practices on total quality management practices, where $\mathrm{R}=0.86$. So human resources management practices are positively related to total quality management practices. The result is consistent with the Wickramasinghe (2012) study which found that human resource management practices have a positive impact on total quality management, firms have become more focused on HRM issues, more closely integrated with business needs, and more involved in strategic decision making due to TQM initiatives and is supported also by González et al. (2016) results which suggest that there is close effect of HRM practices on TQM practices.

H0.2: There is no statistically significant effect at $(\alpha \leq 0.05)$ of total quality management practices on competitive advantage.

Multiple regressions were used to test the effect of human resource management practices on total quality management practices, at a confidence level of $(95 \%)$. 
Table 15. Multiple regression analysis of the effect of human resource management practices on competitive advantage

\begin{tabular}{lllllllll}
\hline Variables & $\mathrm{R}$ & $\mathrm{R}^{2}$ & $\begin{array}{l}\text { Adjusted } \\
\mathrm{R}^{2}\end{array}$ & F-value & Sig*. & $\begin{array}{l}\text { Standardized } \\
\text { Beta }\end{array}$ & $\begin{array}{l}\mathrm{t}- \\
\text { value }\end{array}$ & Sig*. \\
\hline Leadership & 0.827 & 0.684 & 0.679 & 135.634 & $0.00^{*}$ & & & \\
Continuous & & & & & & 0.104 & 3.487 & $0.001^{*}$ \\
Improvement & & & & & 0.143 & 2.552 & $0.011^{*}$ \\
Customer Satisfaction & & & & & & 0.120 & 3.616 & $0.000^{*}$ \\
Employee & & & & & & 0.305 & 5.844 & $0.000^{*}$ \\
Empowerment & & & & & & 0.338 & 5.364 & $0.013^{*}$ \\
Strategic & & & & & & & & \\
\hline
\end{tabular}

As can be shown in table 15 , the correlation coefficient $\mathrm{R}=0.827$ indicates that there is a positive correlation between total quality management practices and competitive advantage. The $\mathrm{R}^{2}$ value is 0.684 ; therefore, the model is regarded as being fit to be used for multiple regressions with the data. The results of the multiple regression analysis that regress the four sub variables total quality management practices are shown on table (15). It shows that the five sub-variables together explained $68.4 \%$ of the variance, where $\left(\mathrm{R}^{2}=0.684, \mathrm{~F}=135.634\right.$, Sig. $\left.=0.00\right)$. Therefore, the null hypothesis is rejected and the alternative hypothesis is accepted, which states that there is effect of total quality management practices (leadership, Continuous Improvement, Customer Satisfaction, Employee Empowerment, strategic) on competitive advantage, at level $(\alpha \leq 0.05)$.

In addition to table (15) shows that the strategic sub-variable has the most contribution on competitive advantage, where (Beta $=0.338$, sig. $=0.00$ ). Thus, it indicates that the strategic sub-variable is the most significant, and it positively and directly regresses to competitive advantage. Followed by employee empowerment sub-variables, where (Beta $=0.305$, sig. $=0.00$ ), then continuous improvement sub variable, where $(B e t a=0.143$, sig. $=0.011)$. Then, customer satisfaction sub variable, where $(B e t a=0.120$, sig. $=0.000)$. Finally, leadership sub-variable where $(B e t a=$ 0.104, sig. $=0.001$ ).

The analysis indicates that there is statistically significance effect of total quality management on competitive advantage, where $\mathrm{R}=0.62$. So, total quality management practices are positively related to competitive advantage. The result is consistent with Firend (2015) study which stated that total quality management practices have a positive significant effect with the competitive advantage. Also, Singla et al. (2013) indicated that there is a close effect of TQM practices on competitive advantage.

H0.3: There is no statistically significant effect at $(\alpha \leq 0.05)$ of human resource management practices on competitive advantage.

Multiple regression was used to test the effect of human resource management practices on competitive advantage, at a confidence level of ( $95 \%)$.

Table 16. Multiple regression analysis of the effect of human resource management practices on competitive advantage

\begin{tabular}{|c|c|c|c|c|c|c|c|c|}
\hline variables & $\mathrm{R}$ & $\mathrm{R}^{2}$ & $\begin{array}{l}\text { Adjusted } \\
\mathrm{R}^{2}\end{array}$ & F-value & Sig*. & $\begin{array}{l}\text { Standardized } \\
\text { Beta }\end{array}$ & $\begin{array}{l}\mathrm{t}- \\
\text { value }\end{array}$ & Sig*. \\
\hline & 0.723 & 0.523 & 0.517 & 86.203 & $0.00^{*}$ & & & \\
\hline $\begin{array}{l}\text { Recruitment } \\
\text { Selection }\end{array}$ & & & & & & 0.348 & 8.311 & $.000^{*}$ \\
\hline Performance Appraisal & & & & & & 0.138 & 2.407 & $.017^{*}$ \\
\hline $\begin{array}{ll}\text { Training } & \text { and } \\
\text { Development } & \end{array}$ & & & & & & 0.125 & 2.240 & $.026^{*}$ \\
\hline $\begin{array}{l}\text { Compensation and } \\
\text { Reward }\end{array}$ & & & & & & 0.332 & 5.367 & $.000^{*}$ \\
\hline
\end{tabular}

As can be shown in Table 16, the correlation coefficient $\mathrm{R}=0.723$ indicates that there is a positive correlation between human resource management practices and competitive advantage. The $\mathrm{R}^{2}$ value is 0.523 ; therefore, the 
model is regarded as being fit to be used for multiple regressions with the data. The results of the multiple regression analysis that regress the four sub variables human resource management practices are shown on table (16). It shows that the four sub-variables together explained $52.3 \%$ of the variance, where $\left(\mathrm{R}^{2}=0.523, \mathrm{~F}=86.203\right.$, Sig. $=0.00)$. Therefore, the null hypothesis is rejected and the alternative hypothesis is accepted, which states that there is effect of human resource management practices (Recruitment \& Selection, Performance Appraisal, Training and Development, Compensation and Reward) on competitive advantage, at level $(\alpha \leq 0.05)$.

In addition to table (16) shows that the recruitment \& selection sub-variable has the most contribution on total quality management practices, where (Beta $=0.348$, sig. $=0.00$ ). Thus, it indicates that the recruitment $\&$ selection sub-variable is the most significant, and it positively and directly regresses to competitive advantage. Followed by compensation and reward sub-variable, where (Beta $=0.332$, sig. $=0.00)$, then performance appraisal sub variable, where (Beta $=0.138$, sig. $=0.017$ ). Finally, training and development sub-variable where $(B e t a=0.125$, sig. $=0.026$ ).

The analysis indicates that there is statistically significance effect of human resource management on competitive advantage. Nikaeen (2012) results that suggest that HRM is a core strategy align internal behavior and skills with the strategic direction of the organization as a whole to enhancements on competitive advantage. In addition, HRM promotes positive relationships among employees who create competitive advantage for firms (Obeidat et al., 2013; Peña-Vinces, 2016).

\section{Discussion}

To gain and sustain competitive advantage in a fast changing industry, it is crucial for a company to understand what the customers perceive (Kumar et al., 2010; Al Azmi et al., 2012; Obeidat et al., 2012). Furthermore, the important of total quality management and human resources management in order to be sustainable in business, as well the future growth and development, of organization (Usrof \& Elmrsey, 2016). The goal of this study was to determine the effect of HRM practices (recruitment and selection, performance appraisals, training and development, compensation and reward), TQM practices (leadership, continuous improvement, customer satisfaction, employee empowerment, and strategic).

The result of multiple regression analyses for the first main hypothesis and four sub-hypothesis where supported by reported results showed that almost all components of HRM (recruitment and selection, performance appraisal, training and development, and compensation and reward) are important to TQM practices. The level of effect of HRM practices on TQM practices were as follows: training and development has the strongest effect with TQM practices, followed by recruitment and selection, then performance appraisal, and finally compensation and reward. The result of multiple regression analyses for the second main hypothesis and five sub-hypothesis indicated that there is statistically effect of total quality management practices on competitive advantage. The level of effect of TQM practices on competitive advantage was as follows: strategic has the strongest effect with competitive advantage, followed by employee empowerment, then continuous improvement, then customer satisfaction, and finally leadership.

The result of multiple regression analyses for the third main hypothesis and four sub-hypothesis indicated that there is statistically effect of human resource management practices on competitive advantage. The level of effect of HRM practices on competitive advantage was as follows: recruitment and selection has the strongest effect with competitive advantage, followed by compensation and reward, then performance appraisal, and finally training and development. In conclusion, the proposed conceptual model represents the factors of human resource management practices, total quality management practices on competitive advantage.

From the practical perspective, this study has six main implications. First, there should be more intensified attention towards increasing the awareness towards HRM role in telecommunication organizations. Hence, HRM department can effectively perform better, and employees can understand the role of the department. Second, HRM department should pay more attention about improving the compensation and reward system in a way to improve the total quality management implementation and improve competitive advantage, the department should pay attention on candidate competencies such as ability to solve problem and ability to work within team (see e.g. Khalayleh et al., 2017). Third, TQM department should pay attention on employee empowerment to improve quality and performance program in telecommunication organizations, and enable all employee to discuss new issues in order reach best quality. Four, organizations should design and develop products to meet market needs through continuous study communication with customers and determine their current requirements, and future expectations. This will increase the customer base and thus increase market share. Five, organization should hold training programs explicitly designed to total quality management on a regular basis to all employees. This will ensure better implementation of quality assurance practices and thus improve the competitive advantage. Finally, organizations must spread the awareness of quality between employees and make them part of the organization's 
culture (see e.g. Shannak \& Obeidat, 2012), and in turn on innovation (see e.g. Obeidat et al., 2017).

This study employed closed-ended questionnaire items to measure the effect of human resource management (HRM) practices, total quality management (TQM) practices, on competitive advantage; this type of questionnaire is easier and quicker for the respondents to complete. However, the responses are limited because the participants could not make any inquiry or explain their answers in more details. The scope of the study is restricted to employees in Jordan with a focus on workers in Amman. As such, the findings may be changed if the study were conducted in other rural areas.

Also, researchers called for more research on the enabling factors of applying electronic services (e.g. Masa'deh, et al., 2008, 2013a, 2013b; Karajeh \& Maqableh, 2014; Maqableh \& Karajeh, 2014; Al-Dmour et al., 2015; Almajali \& Maqableh, 2015; Kateb et al., 2015; Maqableh et al., 2015; Masa'deh, 2016; Tarhini et al., 2015; 2016, 2017a, 2017b; Almajali \& Al-Dmour, 2016; Almajali et al., 2016; Alenezi et al., 2017; Aldmour et al., 2017; Khwaldeh et al., 2017; Mikkawi \&Al-Lozi, 2017; Yassien \& Mufleh, 2017; Tarhini et al., 2018; Al-Dmour et al., 2019), hence, future research is vital to examine these enablers as to assist stakeholders on their decisions on reaching high levels of such services, and in turn enhancing TQM practices in an optimal way.

\section{References}

Abualoush, S. H., Obeidat, A. M., Tarhini, A., Masa'deh, R., \& Al-Badi, A. (2018b). The role of employees' empowerment as an intermediary variable between knowledge management and information systems on employees' performance. VINE Journal of Information and Knowledge Management Systems, 48(2), $217-$ 237.

Abualoush, S., Bataineh, K., \& Alrowwad, A. (2018a). The role of knowledge management process and intellectual capital as intermediary variables between knowledge management infrastructure and organization performance. Interdisciplinary Journal of Information, Knowledge, and Management, 13, 279-309.

Al Azmi, N., Al-Lozi, M., Al-Zu'bi, Z., \& Dahiyat, S. (2012). Patients attitudes toward service quality and its impact on their satisfaction in physical therapy in KSA hospitals. European Journal of Social Sciences, 34(2), 300-314.

Al-dalahmeh, M., Khalaf, R., \& Obeidat, B. (2018). The effect of employee engagement on organizational performance via the mediating role of job satisfaction: The case of IT employees in Jordanian banking sector. Modern Applied Science, 12(6), 17-43.

Al-Dmour, R, Obeidat, B., \& Almajali, D. (2015). The practice of HRIS applications in business organizations in Jordan: An empirical study. 4th Scientific \& Research Conference on New Trends in Business, Management and Social Sciences (COES\&RJ-TK15/1).

Al-Dmour, R., Al Haj Dawood, E., Al-Dmour, H., \& Masa'deh, R. (2019). The effect of customer lifestyle patterns on the use of mobile banking applications in Jordan. Int. J. Electronic Marketing and Retailing, Forthcoming.

Aldmour, R., Masa'deh, R., \& Obeidat, B. (2017). Factors influencing the adoption and implementation of HRIS applications: Are they similar. International Journal of Business Innovation and Research, 14(2), 139-167.

Alenezi, H., Tarhini, A., Alalwan, A., \& Al-Qirim, N. (2017). Factors affecting the adoption of e-government in Kuwait: A qualitative study. Electronic Journal of e-Government, 15(2), 84-102.

Alfalla-Luque, R., Marin-Garcia, J., \& Medina-Lopez, C. (2012). Is worker commitment necessary for achieving competitive advantage and customer satisfaction when companies use HRM and TQM practices?. Universia Business Review, CUARTO trimester, ISSN: 1698-5117:65-88.223.

Almajali, D., \& Al-Dmour, R. (2016). The role of information technology in motivating students to accept elearning adoption in universities: A case study in Jordanian universities. Journal of Business \& Management (COES\&RJ-JBM), 4(1), 36-46.

Almajali, D., \& Maqableh, M. (2015). Assessing the digital divide status of the Jordanian telecentre. International Journal of Communications, Network and System Sciences, 8(11), 428-439.

Almajali, D., Masa'deh, R., \& Al-Lozi, M. (2016). Determinants of the actual use of e-learning systems: An empirical study on Zarqa University in Jordan. Journal of Social Sciences (COES\&RJ-JSS), 5(2), 172-200.

Anil, A., \& Satish, P. (2016). Investigating the relationship between TQM practices and firm's performance: A conceptual framework for Indian organizations. Procedia-Technology, 24(2016), 554-561.

Aragón-Sánchez, A., \& Esteban-Lloret, M. (2010). Training in the Spanish company: Just improving firm pPerformance?. Universia Business Review, 26, 34-57. 
Ching-Chow, Y. (2006). The impact of human resource management practices on the implementation of total quality management: An empirical study on high-tech firms. The TQM Magazine, 18(2), 162-173.

Dedy, A., Zakuan, N., Omain, S., Rahim, K., Ariff, M., Sulaiman, Z., \& Saman, M. (2016). An analysis of the impact of total quality management on employee performance with mediating role of process innovation. IOP Conf. Series: Materials Science and Engineering, 131(2016).

Firend, R. (2015). Contextual examination of TQM practices and competitive advantage in the Malaysianmanufacturing sector. The 2nd World Virtual Conference on Social and Behavioural Science, At Kuala Lumpur, Volume: 28-30.

Gandhi, J. (2014). Competitive advantage through human resource in HDFC bank. Gitarattan International Business School.

Gelade, A., \& Ivery, M. (2003). The impact of human resource management and work climate on organizational performance. Personnel Psychology, 56, 383-404.

González, L., Jimenez-Jimenez, D., \& Martínez-Lorente, A. (2016). Do total quality management and the European foundation for quality management model encourage a quality-oriented human resource management system?. International Journal of Productivity and Quality Management, 17(3), 308.

Jime'nez-Jime'nez, M. (2009). The performance effect of HRM and TQM: A study in Spanish organization. International Journal of Operations \& Production Management, 29(12), 266-289.

Karajeh, H., \& Maqableh, M. (2014). Security of cloud computing environment. The 23rd IBIMA Conference on Vision 2020: Sustainable Growth, Economic Development, and Global Competitiveness, USA, 2202-2215.

Kateb, M., Swies, R., Obeidat, B., \& Maqableh, M. (2015). An investigation on the critical factors of information system implementation in Jordanian information technology companies. European Journal of Business and Management, 7(36), 11-28.

Kaur, P., \& Sharma, S. (2014). Evaluating the relationship and influence of critical success factors of TQM on business performance: Evidence from SMEs of manufacturing sector. IUP Journal of Operations Management, 13(4), 17-30.

Khalayleh, W., Masa'deh, R., \& Al-Lozi, M. (2017). Administrative empowerment and its role on the work teams Performance: A literature review. Journal of Social Sciences (COES\&RJ-JSS), 6(4), 851-868.

Khwaldeh, S., Al-Hadid, I., Masa'deh, R., \& Alrowwad, A. (2017). The association between e-services web portals information quality and ICT competence in the Jordanian universities. Asian Social Science, 13(3), 156-169.

Kumar, P., Clegg, B., \& Bennett, D. (2010). Managing enterprise resource planning projects. Business Process Management Journal, 16(2), 282-296.

Maqableh, M., \& Karajeh, H. (2014). Job scheduling for cloud computing using neural networks. Communications and Network, 6(3), 191-200.

Maqableh, M., Rajab, L., Quteshat, W., Khatib, T., \& Karajeh, H. (2015). The impact of social media networks websites usage on students' academic performance. Communications and Network, 7(4), 159-171.

Masa'deh, R. (2016). The role of knowledge management infrastructure in enhancing job satisfaction at Aqaba five star hotels in Jordan. Communications and Network, 8(4), 219-240.

Masa'deh, R., Alrowwad, A., Alkhalafat, F., Obeidat, O., \& Abualoush, S. (2018). The role of corporate social responsibility in enhancing firm performance from the perspective of IT employees in Jordanian banking sector: The mediating effect of transformational leadership. Modern Applied Science, 12(7), 1-26.

Masa'deh, R., Gharaibeh, A., Maqableh, M., \& Karajeh, H. (2013a). An empirical study of antecedents and outcomes of knowledge sharing capability in Jordanian telecommunication firms: A structural equation modeling approach. Life Science Journal, 10(4), 2284-2296.

Masa'deh, R., Hunaiti, Z., \& Bani Yaseen, A. (2008). An integrative model linking IT-business strategic alignment and firm performance: The mediating role of pursuing innovation and knowledge management strategies. Communications of the International Business Information Management Association (IBIMA) Journal.

Masa'deh, R., Shannak, R., \& Maqableh, M. (2013b). A structural equation modeling approach for determining antecedents and outcomes of students' attitude toward mobile commerce adoption. Life Science Journal, 10(4), 2321-2333.

Mikkawi, B., \& Al-Lozi, M. (2017). The impact of knowledge management infrastructure on academic staff 
effectiveness: An empirical study at The University of Jordan. Jordan Journal of Business Administration, 13(1), 95-127.

Nikaeen, M. (2012). Using competency models to improve HRM. Ideal Type of Management, 1(1), 59-68.

Obeidat, B., El-Rimawi, S., Maqableh, M., \& Al-Jarrah, I. (2013). Evaluating the profitability of the Islamic banks in Jordan. European Journal of Economics, Finance and Administrative Sciences, 56, 27-36.

Obeidat, B., Masa'deh, R., \& Abdallah, A. (2014). The relationships among human resource management practices, organizational commitment, and knowledge management processes: A structural equation modeling approach. International Journal of Business and Management, 9(3).

Obeidat, B., Sweis, R., Zyod, D., \& Alshurideh, M. (2012). The effect of perceived service quality on customer loyalty in internet service providers in Jordan. Journal of Management Research, 4(4), 224-242.

Obeidat, B., Tarhini, A., \& Aqqad, N. (2017). The impact of intellectual capital on innovation via the mediating role of knowledge management: A structural equation modeling approach. International Journal of Knowledge Management Studies, 8(3/4), 273-298.

Pankaj, M. (2012). Implementing a functional ISO 9000 quality management system in MSMES. Indian Journal of Management Science, 1, 16-23.

Peña-Vinces, J. (2016). The mediator role of hierarchical distance on social processes-HRM practices: An empirical analysis of Spanish firms. International Journal of Organizational Leadership, 5(2016), 172-190.

Sekaran, U., \& Bougie, R. (2010). Research methods for business: A skill building approach (5th ed.). New York, NY: John Wiley \& Sons Ltd.

Shannak, R., \& Obeidat, B. (2012). Culture and the implementation process of strategic decisions in Jordan. Journal of Management Research, 4(4), 257-281.

Singla, N., Khanduja, D., \&Singla, T. (2013). A TQM implementation model for enhancing competitiveness of Indian manufacturing firms. International Journal of Perform ability Engineering, 9(4), 387.

Sweis, R., ElGhawi, H., AlSaleh, N., Al-Zu'bi, Z., \& Obeidat, B. (2015). Benchmarking of TQM: The case of Hikma Pharmaceuticals company. Benchmarking: An International Journal, 22(3).

Tamer, K., \& Darwish (2009). The impact of strategic human resource management implementation on firm performance. BBS Doctoral Symposium 23rd \&24th March 2009.

Tarhini, A., Alalwan, A., Al-Qirim, N., \& Algharabat, R. (2018). An analysis of the factors influencing the adoption of online shopping. International Journal of Technology Diffusion (IJTD), 9(3), 68-87.

Tarhini, A., Al-Badi, A., Almajali, M., \& Alrabayaah, S. (2017a). Factors influencing employees' intention to use cloud computing. Journal of Management and Strategy, 8(2), 47.

Tarhini, A., Al-Busaidi, K., Bany Mohammed, A., \& Maqableh, M. (2017b). Factors influencing students' adoption of e-learning: A structural equation modeling approach. Journal of International Education in Business, 10(2), 164-182.

Tarhini, A., Bany Mohammed, A., \& Maqableh, M. (2016). Modeling factors affecting student's usage behaviour of e-learning systems in Lebanon. International Journal of Business and Management, 11(2), 299.

Tarhini, A., Mgbemena, C., \& Trab, MSA. (2015). User adoption of online banking in Nigeria: A qualitative study. Journal of Internet Banking and Commerce, 20(3), 1-8.

Todeva, E., \& John, R. (2001). Shaping the competition and building competitive advantage in the global telecommunication industry: The case of British telecommunications plc. Eam 9th International Conference 17-21 June 2001, Costa Rica.

Usrof, H., \& Elmorsey, R. (2016). Relationship between HRM and TQM and its influence on organizational sustainability. IJARA, 6(2), 21-33.

Velmurugan, S., \& Akhilesh, B. (2013). Sustained competitive advantage: Strategic HRM initiatives and consequences in Indian context. International Journal of Social, Behavioral, Educational, Economic and Management Engineering, 7(8).

Wickramasinghe, V. (2012). Influence of total quality management on human resource management practices: An exploratory study. International Journal of Quality \& Reliability Management, 29(8), 836-850.

Wiengartena, F., Fynesb, B., Chengc, E., \& Chavez, R. (2013). Taking an innovative approach to quality practices: 
Exploring the importance of a company's innovativeness on the success of TQM practices. International Journal of Production Research, 51(10), 3055-3074.

Yassien, E., \& Mufleh, M. (2017). The impact of ERP system's usability on enterprise resource planning project implementation success via the mediating role of user satisfaction. Journal of Management Research, 9(3), 49-71.

\section{Copyrights}

Copyright for this article is retained by the author(s), with first publication rights granted to the journal.

This is an open-access article distributed under the terms and conditions of the Creative Commons Attribution license (http://creativecommons.org/licenses/by/4.0/). 